\title{
Healthy aging from the perspective of the elderly: an integrative review
}

\author{
Renata Evangelista Tavares' \\ Maria Cristina Pinto de Jesus ${ }^{2}$ \\ Daniel Rodrigues Machado ${ }^{3}$ \\ Vanessa Augusta Souza Braga' \\ Florence Romijn Tocantins ${ }^{4}$ \\ Miriam Aparecida Barbosa Merighi ${ }^{5}$
}

Abstract

Objective: to identify the perspective of elderly persons on healthy aging as described by scientific literature. Method: a descriptive integrative review type study was performed, guided by the question: what knowledge has been produced about healthy aging from the perspective of the elderly? It was carried out using the Scopus Info Site (SCOPUS), Cumulative Index to Nursing \& Allied Health Literature (CINAHL), Medical Literature Analysis and Retrieval System Online (MEDLINE), Literature of Latin America and the Caribbean (LILACS), EMBASE and WEB OF SCIENCE databases and in the directory of the Scientific Electronic Library Online Journals (SciELO), for literature published in the period between 2005 and 2016. Result: Eleven papers were regarded as eligible for this review. These studies revealed that healthy aging is related to different health dimensions: biological (adoption of healthy habits and behaviors with self-responsibility), psychological (feelings of optimism and happiness), spiritual (faith and religiosity) and social (reciprocity in social support factors and the capacity to live autonomously and independently). Conclusion: the synthesis of knowledge on healthy aging from the perspective of the elderly can support the actions of professionals who work with this population group to encourage and value the social determinants involved, so overcoming the exclusive focusing on the adoption of habits and behaviors inherent to lifestyle to achieve aging in a healthy way.

\footnotetext{
Universidade de São Paulo, Escola de Enfermagem, Programa de Pós-Graduação em Enfermagem. São Paulo, SP, Brasil.

2 Universidade Federal de Juiz de Fora, Faculdade de Enfermagem, Departamento de Enfermagem Básica. Juiz de Fora, MG, Brasil.

3 Secretaria Municipal de Saúde de Astolfo Dutra. Astolfo Dutra, MG, Brasil.

4 Universidade Federal do Estado do Rio de Janeiro, Escola de Enfermagem Alfredo Pinto, Departamento de Enfermagem em Saúde Pública. Rio de Janeiro, RJ, Brasil.

5 Universidade de São Paulo, Escola de Enfermagem, Departamento de Enfermagem Materno-Infantil e Psiquiátrica. São Paulo, SP, Brasil.
}

Keywords: Aging. Health of the Elderly. Review. 


\section{INTRODUCTION}

The elderly represent $12 \%$ of the world's population, and this figure is expected to double by $2050^{1}$ and triple by $2100^{2}$. Greater longevity can be considered a success story for mankind ${ }^{3}$, and these extra years of life allow people to plan their future in a different manner to previous generations, depending on one central element: health ${ }^{4}$.

With this understanding, public policies have emphasized the positive meaning of aging and the contribution the elderly can make to society with their wealth of knowledge, skills and experiences in everyday life and work ${ }^{3,5}$. For this positive sense of aging, different terms are used: successful aging, active aging and, more recently, the resumption of the term healthy aging, proposed by the World Health Organization (WHO) ${ }^{3}$.

The WHO defines healthy aging as the "process of development and maintenance of functional capacity that allows well-being at an advanced age" ${ }^{13,4}$. Functional capacity, in turn, can be understood as the combination of the intrinsic capacity of the individual, the relevant environmental characteristics and the interactions between the individual and these characteristics ${ }^{3}$. Intrinsic capacity is the articulation of physical and mental abilities (including psychosocial) ${ }^{3}$. Environmental characteristics are the context of life, including social relations. Well-being is unique and permeated with subjective aspirations, including feelings of fulfillment, satisfaction and happiness ${ }^{3}$.

Thus, the understanding of healthy aging, as defined by the WHO, is comprehensive and relevant for all elderly people, even for those living with chronic diseases. It is also not centered on the absence of aggravations, nor is it restricted to the functionality of the elderly. Instead, it is based on a process that will allow the construction of skills that will enable elderly individuals to experience aging in the best possible way ${ }^{4}$.

In addition to the comprehensive WHO understanding of healthy aging, it is also worth exploring the collected scientific evidence on the perspective of the elderly on this issue, as they are the main actors in this context. This knowledge may provide additional information to support interventions and care for this group, and contribute to one of the guidelines of the Global Strategy and Plan of Action for Aging and Health 2016-2020, which encourages the construction and synthesis of evidence on healthy aging ${ }^{6}$. In this context, the present study aimed to identify the perspective of the elderly on healthy aging as described in scientific productions.

METHOD

An integrative literature review was performed, allowing the identification of themes or problems relevant to the field of health and public policy, through the gathering, critical appreciation and synthesis of knowledge about the subject under investigation ${ }^{7}$. Such a method contributes to Evidence-Based Practice, following a standard of excellence regarding methodological rigor ${ }^{8}$.

This integrative review was performed in five stages ${ }^{7}$ in the first stage, the research question was formulated: what knowledge has been produced about healthy aging from the perspective of the elderly? The second stage involved the literature search through a survey of the scientific productions carried out in February 2017 in the main databases of the area of health: Scopus Info Site (SCOPUS), Cumulative Index to Nursing \& Allied Health Literature (CINAHL), Medical Literature Analysis and Retrieval System Online (MEDLINE), Literature of Latin America and the Caribbean (LILACS), EMBASE, WEB OF SCIENCE and in the journal directory of the Scientific Electronic Library Online (SciELO). The period from 2005 to 2016 was used as a temporal cut-off point, with the start date based on the publication of the document Active aging: a WHO health policy?.

The search was carried out based on the key-word "Healthy aging" and the descriptor "Aged", obtained from the Health Sciences Descriptors (DECS) and the synonyms "elderly", "senior" and "older people". It was decided to use terms in English and the Bolean operators AND and OR, as shown in Chart 1.

To compose the sample, the following inclusion criteria were used: original articles published in the period from 2005 to 2016, electronically available in full in the English language, which addressed the 
perspective of the elderly on healthy aging. Literature reviews, annals of scientific events, experiment reports, dissertations and theses were excluded.
The inclusion and exclusion criteria were applied and allowed the selection of 11 articles to make up the study sample, as shown in Figure 1.

Chart 1. Search strategy and articles found in databases and in the search directory. São Paulo, 2017.

\begin{tabular}{|l|l|l|}
\hline Database & Search strategy & $\begin{array}{l}\text { Articles } \\
\text { found }\end{array}$ \\
\hline SCOPUS & "Healthy aging” AND (“aged” OR “elderly” OR “senior” OR “older people”) & 77 \\
\hline CINAHL & "Healthy aging” AND (“aged” OR “elderly” OR “senior” OR “older people”) & 14 \\
\hline MEDLINE & "Healthy aging” AND (“aged” OR “elderly” OR “senior” OR “older people”) & 24 \\
\hline LILACS & "Healthy aging” AND (“aged” OR “elderly” OR “senior” OR “older people”) & 2 \\
\hline EMBASE & Emtree terms: "Healthy aging” AND “aged” & 6 \\
\hline WEB OF SCIENCE & "Healthy aging” AND (“aged” OR “elderly” OR “senior” OR “older people”) & 43 \\
\hline SciELO & Keywords: "Healthy aging” AND “elderly” & 11 \\
\hline Total & & 177 \\
\hline
\end{tabular}

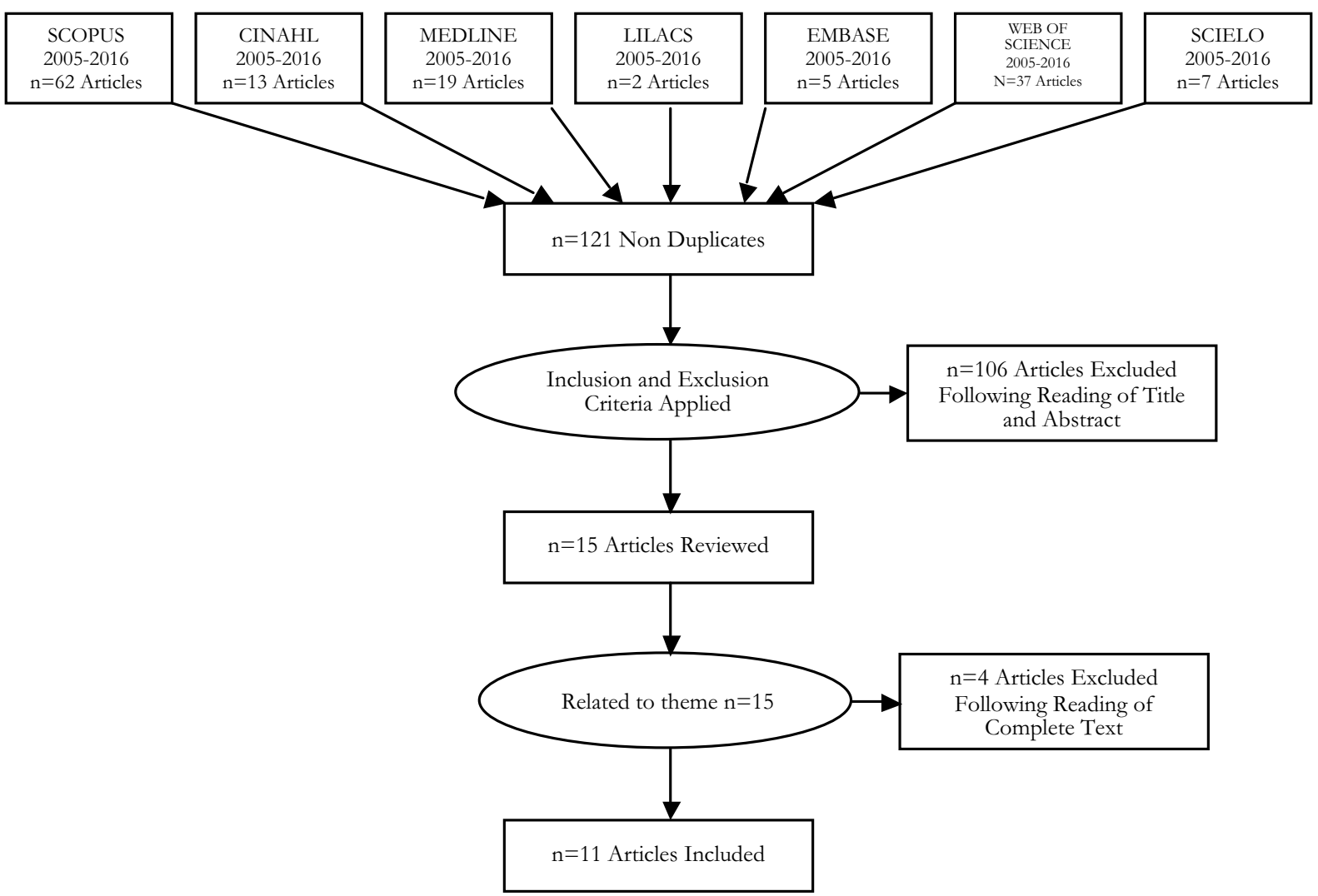

Figure 1. Diagram of the result of applying the inclusion and exclusion criteria of the study. São Paulo, 2017. 
In the third stage a critical evaluation of the scientific productions that met the established criteria was carried out. The identified articles were evaluated for rigor, credibility, and relevance through the Critical Appraisal Skills Programme checklist (CASP). This instrument classifies the studies into two categories: A and B. Those classified as Category A present a small risk of bias, as they meet at least nine of the ten topics: 1) clear and justified objective; 2) methodological design appropriate for the objectives; 3) methodological procedures presented and discussed; 4) intentional sample selection; 5) data collection, instruments and saturation process described; 6) relationship between researcher and researched; 7) ethical aspects; 8) dense and substantiated analysis; 9) results presented and discussed, pointing out the credibility and use of triangulation; 10) description of the contributions, implications of the knowledge generated and its limitations ${ }^{10}$. Category B included those with a moderate risk of bias, that is, those that meet at least five of the ten topics ${ }^{10}$.

The CASP checklist was applied independently by three of the authors in order to guarantee the reliability of the present study. After CASP classification, a database was elaborated that made it possible to organize and compile the following information from the selected studies: article title, profession of the first author, year of publication, country, journal title, method and results (perspectives of the elderly about healthy aging).

In the fourth stage, the perspectives of the elderly on healthy aging were grouped by similarity of content (Table 2). The results were interpreted based on the literature related to the study theme. Finally, the fifth stage included the presentation of the synthesis of knowledge, contained in the discussion and final considerations section.

\section{RESULTS}

The highest proportion of articles $(27.3 \%)$ was published in 2014. The countries that published the most articles were Brazil (36.3\%), Canada (18.1\%) and Thailand (18.1\%). The professional area which published the most studies were psychologists (54.5\%), followed by nurses $(27.2 \%)$. Most of the journals $(63.6 \%)$ were not specific to geriatrics or gerontology.

All the sampled articles were classified as Category A according to the CASP checklist ${ }^{10}$. In terms of content, the selected studies found that the perspective of the elderly on healthy aging covered the biological, psychological, spiritual and social dimensions.

Chart 2 represents the synopsis of the sampled articles of the integrative review. 
Chart 2. Synopsis of articles included in the integrative review. São Paulo, 2017.

\begin{tabular}{|c|c|c|c|}
\hline Authors/Title & $\begin{array}{l}\text { Year/ } \\
\text { Country }\end{array}$ & $\begin{array}{l}\text { Method/ } \\
\text { Participants/Objectives }\end{array}$ & Elderly persons perception of healthy aging \\
\hline $\begin{array}{l}\text { Wallack EM, Wiseman } \\
\text { HD, Ploughman M/ } \\
\text { Healthy Aging from } \\
\text { the Perspectives of } \\
683 \text { Older People with } \\
\text { Multiple Sclerosis }{ }^{11} \text {. }\end{array}$ & $\begin{array}{l}\text { 2016/ } \\
\text { Canada }\end{array}$ & $\begin{array}{l}\text { Quantitative-qualitative/ } \\
\mathrm{n}=683 \text {. Age: } 55 \text { to } 88 \text { years } \\
\text { / Determine which factors } \\
\text { contributed most to healthy } \\
\text { aging for people with } \\
\text { multiple sclerosis. }\end{array}$ & $\begin{array}{l}\text { Social relationships, positive thinking, } \\
\text { determination, maintain identity, eat healthily, } \\
\text { adequate sleep and rest, high quality of health } \\
\text { care, medication management, alternative } \\
\text { therapies, weight control, being independent, } \\
\text { volunteering, developing spirituality, practice } \\
\text { a religion and have financial security. }\end{array}$ \\
\hline $\begin{array}{l}\text { Stephens C, Breheny } \\
\text { M, Mansvelt J/ Healthy } \\
\text { ageing from the } \\
\text { perspective of older } \\
\text { people: A capability } \\
\text { approach to resilience }{ }^{12} \text {. }\end{array}$ & $\begin{array}{l}2015 / \\
\text { New } \\
\text { Zealand }\end{array}$ & $\begin{array}{l}\text { Qualitative/ } n=145 \text {. } \\
\text { Age: } 63 \text { to } 93 \text { years/ Use } \\
\text { Sem theory to analyze } \\
\text { "functionings" from the } \\
\text { perspective of elderly } \\
\text { persons. }\end{array}$ & $\begin{array}{l}\text { Have physical comfort (adequate housing), } \\
\text { security (financial and physical), autonomy, } \\
\text { happiness, social integration and be able to } \\
\text { contribute (voluntary work). }\end{array}$ \\
\hline $\begin{array}{l}\text { Valer DB, Bierhals } \\
\text { CCBK, Aires M, } \\
\text { Paskulin LMG/ The } \\
\text { significance of healthy } \\
\text { aging for older persons } \\
\text { who participated in } \\
\text { health education groups }{ }^{13} \text {. }\end{array}$ & $\begin{array}{l}2015 / \\
\text { Brasil }\end{array}$ & $\begin{array}{l}\text { Qualitative/ } n=30 \text {. Age: } \\
62 \text { to } 82 \text { years/ Describe } \\
\text { the meaning of healthy } \\
\text { aging for elderly people } \\
\text { who participated in health } \\
\text { education groups of a } \\
\text { Basic Health Unit. in Porto } \\
\text { Alegre, Rio Grande do Sul. }\end{array}$ & $\begin{array}{l}\text { Be physically active, eat suitable food, } \\
\text { care for oneself, don't smoke or drink } \\
\text { alcohol, have adequate sleep and rest, } \\
\text { socialize, perform leisure activities, seek } \\
\text { out healthcare (routine medical check-ups, } \\
\text { examinations, vaccination and absence of } \\
\text { disease), be independent and have positive } \\
\text { feelings. }\end{array}$ \\
\hline $\begin{array}{l}\text { Sixsmith J, Sixsmith } \\
\text { A, Fänge AM, Naumann } \\
\text { D, Kucsera C, Tomsone S } \\
\text { et al./ Healthy ageing and } \\
\text { home: The perspectives } \\
\text { of very old people in five } \\
\text { European countries }{ }^{14} \text {. }\end{array}$ & $\begin{array}{l}\text { 2014/ } \\
\text { Germany } \\
\text { Hungary } \\
\text { Latvia } \\
\text { Sweden } \\
\text { United } \\
\text { Kingdom }\end{array}$ & $\begin{array}{l}\text { Qualitative/ } \mathrm{n}=190 \text {. Age: } 75 \\
\text { to } 89 \text { years/ Understanding } \\
\text { the perspectives of the } \\
\text { elderly on the relationship } \\
\text { between healthy aging and } \\
\text { the home among very old } \\
\text { people in five European } \\
\text { countries. }\end{array}$ & $\begin{array}{l}\text { Feel independent, be able to manage one's } \\
\text { home and have financial security. Have } \\
\text { hobbies and do individual or collective } \\
\text { leisure activities. Eat healthily, don't smoke } \\
\text { or drink alcohol and do physical activities. }\end{array}$ \\
\hline $\begin{array}{l}\text { Waites CE, } \\
\text { Onolemhemhen DN/ } \\
\text { Perceptions of healthy } \\
\text { aging among african- } \\
\text { american and ethiopian } \\
\text { elders }^{15} \text {. }\end{array}$ & $\begin{array}{l}\text { 2014/ } \\
\text { EUA } \\
\text { Ethiopia }\end{array}$ & $\begin{array}{l}\text { Quantitative-qualitative/ } \\
\mathrm{n}=165 \text {. Age: } 50 \text { to } 81 \\
\text { (Ethiopia, } \mathrm{n}=100 \text { ) and } 60 \\
\text { to } 81 \text { years (USA, } \mathrm{n}=65 \text { )/ } \\
\text { Explore the perception of } \\
\text { healthy aging and health } \\
\text { promotion preferences } \\
\text { and practices of African } \\
\text { American and Ethiopian } \\
\text { elderly persons. }\end{array}$ & $\begin{array}{l}\text { Healthy aging for African Americans is } \\
\text { to be independent and able to take care } \\
\text { of oneself; while for Ethiopians, it is to } \\
\text { perform physical activity, the absence of } \\
\text { disease and maintenance of family life. Both } \\
\text { expressed faith and spirituality. }\end{array}$ \\
\hline $\begin{array}{l}\text { Bacsu J, Jeffery B, } \\
\text { Abonyi S, Johnson S, } \\
\text { Novik N, Martz D et al./ } \\
\text { Healthy aging in place: } \\
\text { perceptions of rural older } \\
\text { adults }^{16} \text {. }\end{array}$ & $\begin{array}{l}\text { 2014/ } \\
\text { Canada }\end{array}$ & $\begin{array}{l}\text { Qualitative/ } n=40 \text {. Age: } \\
65 \text { to } 85 \text { years/ Explore } \\
\text { the meanings, experiences } \\
\text { and perceptions of healthy } \\
\text { aging among rural elderly } \\
\text { persons. }\end{array}$ & $\begin{array}{l}\text { Interact socially, stay active, independent, } \\
\text { optimistic and maintain cognitive health. }\end{array}$ \\
\hline $\begin{array}{l}\text { Boratti KLP, Soriano FS/ } \\
\text { The perception of elderly } \\
\text { persons about beliefs on } \\
\text { self-efficacy and healthy } \\
\text { aging }^{17} \text {. }\end{array}$ & $\begin{array}{l}2013 / \\
\text { Brazil }\end{array}$ & $\begin{array}{l}\text { Qualitative/ } n=6 \text {. Age: } 60 \\
\text { to } 80 \text { years/ To verify the } \\
\text { perception of the elderly } \\
\text { about the beliefs of self- } \\
\text { efficacy and healthy aging. }\end{array}$ & $\begin{array}{l}\text { Perform routine activities, contribute, accept } \\
\text { life as it is, have positive thoughts, believe in } \\
\text { God and have health. }\end{array}$ \\
\hline
\end{tabular}


Continuation of Chart 1

\begin{tabular}{|c|c|c|c|}
\hline Authors/Title & $\begin{array}{l}\text { Year/ } \\
\text { Country }\end{array}$ & $\begin{array}{l}\text { Method/ } \\
\text { Participants/Objectives }\end{array}$ & Elderly persons perception of healthy aging \\
\hline $\begin{array}{l}\text { Thanakwang K, } \\
\text { Soonthorndhada K, } \\
\text { Mongkolprasoet J/ } \\
\text { Perspectives on healthy } \\
\text { aging among Thai elderly: } \\
\text { a qualitative study }{ }^{18} \text {. }\end{array}$ & $\begin{array}{l}\text { 2012/ } \\
\text { Thailand }\end{array}$ & $\begin{array}{l}\text { Qualitative/ } n=160 \text {. Age: } \\
60 \text { to } 88 \text { years/ Describe } \\
\text { the aspects of healthy } \\
\text { aging and the factors that } \\
\text { contribute to healthy aging } \\
\text { in Thailand. }\end{array}$ & $\begin{array}{l}\text { Absence of serious chronic diseases, } \\
\text { functional independence, a positive psycho- } \\
\text { emotional perspective, spirituality and make } \\
\text { a social contribution; perform physical } \\
\text { activity, have good nutritional habits, do not } \\
\text { smoke or drink alcohol and manage disease } \\
\text { well. }\end{array}$ \\
\hline $\begin{array}{l}\text { Deponti RN, Acosta } \\
\text { MAF/ Understanding of } \\
\text { the elderly of factors that } \\
\text { influence healthy aging }{ }^{19} \text {. }\end{array}$ & $\begin{array}{l}2010 / \\
\text { Brazil }\end{array}$ & $\begin{array}{l}\text { Qualitative/ } n=30 \text {. Age: } \\
56 \text { to } 85 \text { years/ Investigate } \\
\text { the elderly person's } \\
\text { understanding of what } \\
\text { factors influence Healthy } \\
\text { Aging. }\end{array}$ & $\begin{array}{l}\text { Be enthusiastic, have a positive attitude, be } \\
\text { active, live with joy/fun, be optimistic, have } \\
\text { a young spirit, good memory, friendships, } \\
\text { coexistence with other people and count on } \\
\text { the support of the family. }\end{array}$ \\
\hline $\begin{array}{l}\text { Danyuthasilpe C, } \\
\text { Amnatsatsue K, } \\
\text { Tanasugarn C, } \\
\text { Kerdmongkol P, Steckler } \\
\text { AB/ Ways of healthy } \\
\text { aging: a case study } \\
\text { of elderly people in a } \\
\text { Northern Thai village }{ }^{20} \text {. }\end{array}$ & $\begin{array}{l}\text { 2009/ } \\
\text { Thailand }\end{array}$ & $\begin{array}{l}\text { Qualitative/ } n=7 \text {. age: } 78 \\
\text { to } 85 \text { years/ Explore the } \\
\text { forms of healthy aging } \\
\text { among a specific group of } \\
\text { elderly persons in order to } \\
\text { understand the connection } \\
\text { between healthy aging and } \\
\text { culture. }\end{array}$ & $\begin{array}{l}\text { Eat well, have support from one's family, } \\
\text { practice physical activity and healing, } \\
\text { worship ancestors, don't smoke or drink } \\
\text { alcohol, perform spiritual services and be } \\
\text { interdependent. }\end{array}$ \\
\hline $\begin{array}{l}\text { Cupertino APFB, } \\
\text { Rosa FHM, Ribeiro } \\
\text { PCC/ Definition of } \\
\text { Healthy Aging from the } \\
\text { Perspective of Elderly } \\
\text { Individuals }^{21} \text {. }\end{array}$ & $\begin{array}{l}2007 / \\
\text { Brazil }\end{array}$ & $\begin{array}{l}\text { Qualitative/ } \mathrm{n}=501 \text {. Age: } 60 \\
\text { to } 93 \text { years/ to examine the } \\
\text { definition of healthy aging } \\
\text { in a sample of the elderly } \\
\text { living in the community, } \\
\text { seeking to identify the } \\
\text { multidimensions perceived } \\
\text { by the same. }\end{array}$ & $\begin{array}{l}\text { To have physical health, social relations, eat } \\
\text { healthily, do physical activities, don't smoke } \\
\text { or drink alcohol, leisure, acceptance of this } \\
\text { phase, have faith and spirituality, family } \\
\text { structure, financial stability, do good. }\end{array}$ \\
\hline
\end{tabular}

Chart created by authors.

\section{DISCUSSION}

The sample of articles analyzed was diverse, with studies from each continent: America (Canada, USA, Brazil), Oceania (New Zealand), Europe (Germany, Hungary, Latvia, Sweden, United Kingdom), Africa (Ethiopia) and Asia (Thailand). It has been found that, as addressed in the scientific literature, healthy aging is a global concern ${ }^{3}$.

In terms of the participants, individuals under 60 years of age were considered in two studies. An Ethiopian article included Ethiopians over 50 years of age due to the expectation of life in this country being $54^{15}$. And in New Zealand, New Zealanders aged 55 and over were considered elderly ${ }^{11 .}$
The knowledge produced about the perception of elderly people about healthy aging was discussed through the biological, psychological, spiritual and social dimensions.

\section{Biological dimension}

The elderly perceive healthy aging as the adoption of habits and behaviors inherent to lifestyle, with emphasis on healthy eating ${ }^{11,13,14,18,19-21}$, physical activities ${ }^{13-15,18,20-21}$, and not smoking or drinking alcohol ${ }^{13,14,18,20,21}$. These habits and behaviors are protective factors and help control chronic noncommunicable diseases $(\mathrm{CNCDs})^{22}$, 
which represent the major causes of mortality in the elderly population through outcomes such as ischemic heart disease, strokes and chronic obstructive pulmonary disease $e^{4,22}$.

The set of habits and behaviors described by the elderly is a priority theme in the National Health Promotion Policy (NHPP) in Brazil ${ }^{23}$, and is expected to form part of Primary Health Care (PHC) through advice provided in educational groups on health, medical and nursing consultations and home visits, among other opportunities ${ }^{22}$.

Thus, the efforts of professionals to prevent or control CNCDs focus heavily on the lifestyle of the individual. Such action contributes to the elderly assuming, in an isolated manner, the selfresponsibility of acquiring a healthy lifestyle. From this perspective, scientific literature encompasses two distinct approaches, which involve either stimulating this posture or encouraging it with caution.

An American study ${ }^{24}$ which stimulated selfresponsibility in acquiring a healthy lifestyle considered a model described as a possible basis for enhancing PHC actions among the elderly with chronic conditions. This model consists of four pillars: "centered on the perspective of the elderly" the elderly population considered as a heterogeneous group that requires individualized attention; "goaloriented approach" - setting individualized, specific and achievable goals to be shared with the elderly; "individualized 'training' strategy for behavior change in health" - focused on the elderly and based on instrumentalization with knowledge that allows the awareness that triggers behavioral change to be achieved; and the "context in which healthy behavior occurs" - a network of meaningful relationships for the elderly that contribute to achieving their goals.

In contrast, another American study advocated cautiously encouraging actions aimed at selfresponsibility in the adoption of a healthy lifestyle. It presented in a broad manner the discussion about the poor efficacy of actions directed at an individual lifestyle, emphasizing the need to tackle the deeper causes of CNCDs. It recognizes that the economic and social environment is capable of restricting or increasing opportunities as it interferes in the behavior of the population ${ }^{25}$. As a result, not everyone is able to eat healthily, exercise properly, lose weight and avoid using tobacco, alcohol and other drugs ${ }^{25}$.

In addition to understanding healthy aging as the adoption of habits and behaviors inherent to lifestyle, the elderly emphasized the importance of taking care of one's health. This involves performing routine medical check-ups, examinations, vaccinations ${ }^{13}$ and managing diseases efficiently ${ }^{11,18}$. However, they did not associate healthy aging with disease $e^{11-17,19-21}$.

\section{Psychological Dimension}

In the psychological dimension, the perspectives of the elderly on healthy aging were aggregated, with optimism appearing most frequently ${ }^{11,13,16,18,19}$. The older persons revealed that being positive and optimistic is an essential part of healthy aging, with optimism understood as the expectation that something positive will happen ${ }^{26}$.

Optimism in aging may result from the presence of a social support network, quality of life and individual and social activities within the daily lives of the elderly ${ }^{27}$. Based on this understanding, a Brazilian study brought together scientific productions about optimism and health, and found a significant number of international studies with this theme, considering people with CNCDs. According to these individuals, optimism is considered a factor of protection and coping with the consequences of these injuries ${ }^{28}$.

There is no well-defined concept for happiness as it varies according to the cultural and social context of each country ${ }^{29}$. In South Korea, a study of the elderly revealed an association between family and the perception of happiness. These individuals often described the importance of being together with family and living in peace with relatives ${ }^{29}$. It therefore appears that elderly persons with significant contact with family members and people close to them enjoy a broader sense of well-being than those without such contacts $^{30}$.

The welfare of the elderly is a vital component to be considered in public policies. In 2002, in Madrid, the Second World Assembly on Aging established the International Plan of Action on Aging, listing 
priorities for action which included "well-being in old age $^{131}$. In 2015, the WHO report on aging and health encompassed well-being in the concept of healthy aging, emphasizing the importance of "promoting health and well-being throughout life"s.

Accordingly, in this report, the WHO recommends that to achieve healthy aging, public policies, health services and professionals should work from an intersectoral perspective, connecting the elderly, family and society, and develop actions that promote the development and maintenance of functional capacity as a strategy that allows the well-being of the elderly population ${ }^{3}$.

\section{Spiritual dimension}

This dimension brings together the perspectives of the elderly on healthy aging in relation to faith and spirituality. According to the studies that composed the analyzed sample, faith and spirituality provide support for dealing with the challenges of living with multiple sclerosis ${ }^{11}$ and facing daily difficulties ${ }^{19}$. Most of these studies, however, while recognizing the importance of this theme for healthy aging, did not explore it further ${ }^{12,15,17,21}$, with the exception of the articles on elderly Thai people ${ }^{18,20}$.

For these individuals, food and care of the body are related to spirituality, as well as the practice of healing and worshipping of ancestors. The practice of healing involves taking care of oneself before consulting a doctor (such as body massages with a piece of wood to relieve muscle pain) and worshiping one's ancestors to preserve health, as failing to do so may result in one falling ill ${ }^{18,20}$.

There is evidence that older people tend to be more religious than younger people ${ }^{32}$. Still, the elderly who live with chronic diseases often have a need to feel close to a higher power which gives them the strength to face difficulties ${ }^{33}$.

Religiousness and spirituality can contribute to healthier lifestyles by assigning negative points of view to the consumption of drugs and alcoholic beverages, tobacco use and nonmarital sex, among others $^{32}$. In addition, they can make it possible to deal with stressful life events ${ }^{30}$, contribute to overcoming adversities, such as the loss of loved ones, the loss of physical abilities, and promote meaning in life. Faith can promote virtues such as humility, altruism, compassion, wisdom and gratitude ${ }^{32}$.

\section{Social dimension}

The perspective of the elderly on healthy aging is closely related to social relationships. For these individuals, relating socially $y^{11,13,16,21}$, with the family ${ }^{12,15,19-21}$, friends ${ }^{12,14,19}$, or with a partner ${ }^{12}$ or engaging in collective leisure activities ${ }^{13}$ are ingredients for healthy aging.

It was also emphasized that social relations with family members, children and partners or informal relationships with friends, neighbors and colleagues, as well as formal relationships with health and community services, are fundamental to the wellbeing of the elderly ${ }^{30}$ and to healthy aging. Yet strong social relationships can increase quality of life, and longevity and promote resilience ${ }^{3}$.

There is ambivalence ${ }^{3}$ involved with social relations as both actors involved in the relationship are influenced in a reciprocal and singular way. At the same time, one person may influence or contribute to a greater extent than the other. In this case, when the elderly participant in the social relationship receives support through such an interaction, it can be said that social support is provided ${ }^{34}$. This can alleviate everyday problems and promote physical and mental health ${ }^{35}$. As a support for health actions, social support can also contribute to increasing the sense of joy, self-esteem and self-confidence of an individual ${ }^{34,35}$.

In addition to being supported, the elderly can also provide support. For many, supporting others is more important than receiving support, contributing to a strengthening of their self-esteem and social involvement ${ }^{30}$. This can be seen by their social contributions ${ }^{17,18}$ and desire to do good ${ }^{21}$ through voluntary work ${ }^{11,18}$.

According to the $\mathrm{WHO}$, voluntary work can positively influence the health of the elderly, favoring self-perception of health, reducing systemic arterial hypertension, increasing physical strength and gait 
speed and reducing depressive symptoms ${ }^{3}$, especially as it is socially valued and publicly recognized. It is worth mentioning that voluntary work should respect the autonomy of the elderly, or it may influence their mental health in a harmful way instead of bringing benefits ${ }^{36}$.

Autonomy and independence were also perceived by the elderly as components for healthy aging. Autonomy is the ability to act and take decisions ${ }^{13}$ while independence is the ability to perform activities without the help of other people. In this sense, the studies reviewed related autonomy to financial security ${ }^{11,12,14}$, which has also been found to be a component of healthy aging ${ }^{3}$. In Brazil, the National Policy for the Health of the Elderly states that income contributes to the health of the elderly, demonstrating that being healthy should include financial independence, physical health, mental health, functional capacity and social support ${ }^{37}$. This policy also stresses that care for the elderly, at all levels, must preserve their autonomy and independence ${ }^{37}$.

Independence for the elderly involves caring for oneself $f^{15,16}$ and for others ${ }^{13}$, enjoying activities ${ }^{13,16}$ and home management ${ }^{14}$. Elderly persons with multiple sclerosis connected the environment with independence when they noted the need to adapt the environment in which they lived to be able to live independently ${ }^{11}$. It is because of this insight that the WHO highlights the importance of considering the environment in the promotion of healthy aging, noting that it can be a resource or a barrier ${ }^{3}$.

Unlike Western cultures, studies that focused on Thai seniors discussed interdependence, rather than autonomy and independence. In the Thai culture the elderly are a central part of rituals, their children and grandchildren demonstrate love and respect towards them, they receive support from their families in many ways (respect, love, care, financial, clothing, among others) and they are honored in village festivals ${ }^{18,20}$. This interdependence favors selfesteem, involves companionship, contact, concern and reciprocity in care ${ }^{18,20}$.

One of the limitations of this study was that it featured a small sample of articles, although the survey reflected the perception of the elderly in diversified countries in relation to cultural, political and social aspects, which influence the population's perception of healthy aging directly and indirectly.

The synthesis of knowledge about healthy aging from the perspective of the elderly can support the actions of professionals who work with this population in order to stimulate and value the social determinants involved, leading to guidance directed exclusively towards the adoption of habits and behaviors inherent to lifestyle in order to age in a healthy manner.-

\section{CONCLUSION}

The study revealed that the perception of healthy aging brings together biological, psychological, spiritual and social dimensions. In the biological dimension, the need to adopt habits and behaviors inherent to lifestyle to age in a healthy way was clear. Such a position encompasses two distinct discussions: stimulating this behavior or encouraging it with caution, recognizing that the economic and social environment can restrict or expand opportunities, and as a consequence interfere in the behavior of the population.

In the psychological dimension, the elderly described optimism and happiness as important for healthy aging. In the spiritual dimension, most of the elderly recognized faith and spirituality as elements for healthy aging, yet the authors of the studies did not explore this dimension further, except for studies involving Thai seniors.

In the social dimension, social relationships with family, friends and partners were highlighted. There is some ambivalence in this dimension, which is evidenced by the need to receive support and simultaneously support and contribute, mainly through voluntary work.

In this context, further studies are recommended to broaden knowledge of the perspective of the elderly on healthy aging in order to contribute to one of the guidelines of the Global Strategy and Plan of Action for Aging and Health 2016-2020, and to strengthen the relationship between social determinants and healthy aging. 


\section{REFERENCES}

1. Suzman R, Beard JR, Boerma T, Chatterji S. Health in an ageing world: what do we know? Lancet [Internet]. 2015 [acesso em 15 jun. 2017];9967(385):484-6. Disponível em: https://www.ncbi.nlm.nih.gov/ pubmed/25468156

2. United Nations. Departament of Economic and Social Affairs. World population prospects the 2015 revision: key findings and advanced tables [Internet]. New York: United Nations; 2015 [acesso em 15 jun. 2017]. Disponível em: http://esa.un.org/unpd/wpp/ publications/files/key_findings_wpp_2015.pdf

3. World Health Organization. World report on ageing and health [Internet]. Geneva: WHO; 2015 [acesso em 15 jun. 2017]. Disponível em: http://apps.who. int/iris/bitstream/10665/186463/1/9789240694811_ eng.pdf?ua $=1$

4. Beard JR, Officer A, De Carvalho IA, Sadana R, Pot AM, Michel JP, et al. The World report on ageing and health: a policy framework for healthy ageing. Lancet [Internet]. 2016 [acesso em 15 jun. 2017];387(10033):2145-54. Disponível em: https:// www.ncbi.nlm.nih.gov/pmc/articles/PMC4848186/ pdf/nihms-737759.pdf

5. Cannon ML. What is aging? Dis Mon [Internet]. 2015 [acesso em 15 jun. 2017];61(11):454-9. Disponível em: http://www.diseaseamonth.com/article/S00115029(15)00143-1/abstract

6. World Health Organization. Global strategy and action plan on ageing and health (2016-2020) [Internet]. Geneva: WHO; 2016 [acesso em 15 jun. 2017]. Disponível em: http://who.int/ageing/GSAPSummary-EN.pdf

7. Whittemore R, Knafl K. The integrative review: updated methodology. J Adv Nurs [Internet]. 2005 [acesso em 15 jun. 2017];52(5):546-53. Disponível em: https://www.ncbi.nlm.nih.gov/pubmed/16268861

8. Soares CB, Hoga LAK, Peduzzi M, Sangaleti C, Yonekura T, Silva DRAD. Integrative review: concepts and methods used in nursing. Rev Esc Enferm USP [Internet]. 2014 [acesso em 15 jun. 2017];48(2):329-39. Disponível em: http://www.scielo.br/pdf/reeusp/ v48n2/0080-6234-reeusp-48-02-335.pdf

9. World Health Organization. Envelhecimento ativo: uma política de saúde [Internet]. Brasília, DF: OPAS; 2005 [acesso em 15 jun. 2017]. Disponível em: http://bvsms.saude.gov.br/bvs/publicacoes/ envelhecimento_ativo.pdf
10. Critical Appraisal Skills Programme CASP: Qualitative Research Checklist [Internet]. [Sem Local]: [Sem Publicador]; 2017. Disponível em: http:// docs.wixstatic.com/ugd/dded87_25658615020e427da 194a325e7773d42.pdf

11. Wallack EM, Wiseman HD, Ploughman M. Healthy aging from the perspectives of 683 older people with multiple sclerosis. Mult Scler Int [Internet]. 2016 [acesso em 15 jun. 2017];1-10. Disponível em: https:// www.hindawi.com/journals/msi/2016/1845720/

12. Stephens C, Breheny M, Mansvelt J. Healthy ageing from the perspective of older people: a capability approach to resilience. Psychol Health [Internet]. 2015 [acesso em 15 jun. 2017];30(6):715-31. Disponível em: https://www.ncbi.nlm.nih.gov/pubmed/24678916

13. Valer DB, Bierhals CCBK, Aires M, Paskulin LMG. The significance of healthy aging for older persons who participated in health education groups. Rev Bras Geriatr Gerontol [Internet]. 2015 [acesso em 15 jun. 2017];18(4):809-19. Disponível em: http://www.scielo. br/pdf/rbgg/v18n4/1809-9823-rbgg-18-04-00809.pdf

14. Sixsmith J, Sixsmith A, Fänge AM, Naumann D, Kucsera C, Tomsone S, et al. Healthy ageing and home: the perspectives of very old people in five European countries. Soc Sci Med [Internet]. 2014 [acesso em 15 jun. 2017];106:1-9. Disponível em: https://www.ncbi.nlm.nih.gov/pubmed/24524960

15. Waites CE, Onolemhemhen DN. Perceptions of Healthy Aging among African-American and Ethiopian Elders. Ageing Int [Internet]. 2014 [acesso em 15 jun. 2017];39(4):369-84. Disponível em: https:// link.springer.com/article/10.1007/s12126-014-9203-1

16. Bacsu J, Jeffery B, Abonyi S, Johnson S, Novik N, Martz D, et al. Healthy aging in place: perceptions of rural older adults. Educ Gerontol [Internet]. 2014 [acesso em 15 jun. 2017];40(5):327-37. Disponível em: http://www.tandfonline.com/doi/abs/10.1080/03601 277.2013.802191

17. Boratti KLP, Soriano FS. A percepção de idosas acerca das crenças de autoeficácia e envelhecimento saudável. Aletheia [Internet]. 2013 [acesso em 15 jun. 2017];42:51-61. Disponível em: http://pepsic.bvsalud. org/pdf/aletheia/n42/n42a05.pdf

18. Thanakwang K, Soonthorndhada K, Mongkolprasoet J. Perspectives on healthy aging among thai elderly: a qualitative study. Nurs Health Sci [Internet]. 2012 [acesso em 15 jun. 2017];14(4):472-9 Disponível em: https://www.ncbi.nlm.nih.gov/pubmed/23186522 
19. Deponti RN, Acosta MAF. Compreensão dos idosos sobre os fatores que influenciam no envelhecimento saudável. Estud Interdiscipl Envelhec [Internet]. 2010 [acesso em 15 jun. 2017];15(1):33-52. Disponível em: http://seer.ufrgs.br/RevEnvelhecer/article/ view/9520/10908

20. Danyuthasilpe C, Amnatsatsue K, Tanasugarn C, Kerdmongkol P, Steckler AB. Ways of healthy aging: a case study of elderly people in a Northern Thai village. Health Promot Int [Internet]. 2009 [acesso em 15 jun. 2017];24(4):394-403. Disponível em: https:// www.ncbi.nlm.nih.gov/pubmed/19850569

21. Cupertino APFB, Rosa FHM, Ribeiro PCC. Definição de envelhecimento saudável na perspectiva de indivíduos idosos. Psicol Reflex Crit [Internet]. 2007 [acesso em 15 jun. 2017];20(1):816. Disponível em: http://www.scielo.br/pdf/prc/ v20n1/a11v20n1.pdf

22. Ministério da Saúde. Estratégias para o cuidado da pessoa com doença crônica [Internet]. Brasília, DF: MS; 2014 [acesso em 15 jun. 2017]. (Cadernos de Atenção Básica, n. 35). Disponível em: http://bvsms. saude.gov.br/bvs/publicacoes/estrategias_cuidado_ pessoa_doenca_cronica_cab35.pdf

23. Ministério da Saúde. Política Nacional de Promoção da Saúde: revisão da Portaria MS/GM no 687, de 30 de março de 2006 [Internet]. Brasília, DF: MS; 2014. [acesso em 15 jun. 2017] Disponível em: http:// bvsms.saude.gov.br/bvs/publicacoes/politica_ nacional_promocao_saude_pnaps.pdf

24. Potempa KM, Butterworth SW, Flaherty-Robb MK, Gaynor WL. The Healthy Ageing Model: health behaviour change for older adults. Collegian [Internet]. 2010 [acesso em 15 jun. 2017];17(2):515. Disponível em: https://www.ncbi.nlm.nih.gov/ pubmed/20738056

25. Mariner WK. Beyond lifestyle: governing the social determinants of health. Am J Law Med [Internet]. 2016 [acesso em 15 jun. 2017];42(2-3):284-309. Disponível em: http://journals.sagepub.com/doi/ abs/10.1177/0098858816658268

26. Vilhena E, Pais-Ribeiro J, Silva I, Pedro L, Meneses $\mathrm{RF}$, Cardoso H, et al. Optimism on quality of life in portuguese chronic patients: moderator/mediator? Rev Assoc Med Bras [Internet]. 2014 [acesso em 15 jun. 2017];60(4):373-80. Disponível em: http:// www.scielo.br/pdf/ramb/v60n4/0104-4230ramb-60-04-0373.pdf
27. Silva PA. Individual and social determinants of selfrated health and well-being in the elderly population of Portugal. Cad Saúde Pública [Internet]. 2014 [acesso em 15 jun. 2017];30(11):2387-400. Disponível em: http://www.scielo.br/pdf/csp/v30n11/0102311X-csp-30-11-2387.pdf

28. Santos MC, Wechsler SM. Análise das publicações científicas sobre otimismo em saúde no último triênio. Psicol Argum [Internet]. 2015 [acesso em 15 jun. 2017];33(83):470-82. Disponível em: http://www2.pucpr.br/reol/pb/index.php/ pa?dd1 $=16210 \& d d 99=$ view $\&$ dd $98=$ pb

29. Jeon SW, Han C, Lee J, Lim JH, Jeong H, Park MH, et al. Perspectives on the happiness of communitydwelling elderly in Korea. Psychiatry Investig [Internet]. 2016 [acesso em 15 jun. 2017];13(1):50-7. Disponível em: https://www.ncbi.nlm.nih.gov/pmc/ articles/PMC4701685/

30. Mantovani EP, Lucca SR, Neri AL. Associations between meanings of old age and subjective wellbeing indicated by satisfaction among the elderly. Rev Bras Geriatr Gerontol [Internet]. 2016 [acesso em 15 jun. 2017];19(2):203-22. Disponível em: http:// www.scielo.br/pdf/rbgg/v19n2/en_1809-9823rbgg-19-02-00203.pdf

31. Fernandes MTO, Soares SM. The development of public policies for elderly care in Brazil. Rev Esc Enferm USP [Internet]. 2012 [acesso em 15 jun. 2017];46(6):1494-502. Disponível em: http://www. scielo.br/pdf/reeusp/v46n6/en_29.pdf

32. Zimmer Z, Jagger C, Chiu C, Ofstedal MB, Rojo F, Saito Y. Spirituality, religiosity, aging and health in global perspective: a review. SSM Popul Health [Internet]. 2016 [acesso em 15 jun. 2017];2:373-81. Disponível em: http://www.sciencedirect.com/ science/article/pii/S2352827316300179

33. Palencia IPG, Banquett DC, Quintana MC, Villamizar AL, Mendoza YV. Spirituality and religiosity in elderly adults with chronic disease. Invest Educ Enferm [Internet]. 2016 [acesso em 15 jun. 2017];34(2):235-42 Disponível em: http://www. scielo.org.co/pdf/iee/v34n2/v34n2a02.pdf

34. Kool MB, Van Middendorp H, Lumley MA, Bijlsma JW, Geenen R. Social support and invalidation by others contribute uniquely to the understanding of physical and mental health of patients with rheumatic diseases. J Health Psychol [Internet]. 2013 [acesso em 15 jun. 2017];18(1):86-95. Disponível em: https:// www.ncbi.nlm.nih.gov/pubmed/22363049 
35. Wang X. Subjective well-being associated with size of social network and social support of elderly. J Health Psychol [Internet]. 2014 [acesso em 15 jun. 2017];21(6):1037-42. Disponível em: https://www. ncbi.nlm.nih.gov/pubmed/25104778

36. Tomioka K, Kurumatani N, Hosoi H. Positive and negative influences of social participation on physical and mental health among communitydwelling elderly aged 65-70 years: a cross-sectional study in Japan. BMC Geriatr [Internet]. 2017 [acesso em 15 jun. 2017];17(1):1-13. Disponível em: https:// www.ncbi.nlm.nih.gov/pmc/articles/PMC5437627/ pdf/12877_2017_Article_502.pdf

37. Ministério da Saúde. Política Nacional de Saúde da Pessoa Idosa. Portaria n 2.528 de 19 de outubro de 2006 [Internet]. Brasília, DF: MS; 2006 [acesso em 15 jun. 2017]. Disponível em: http://www.saudeidoso.icict.fiocruz.br/pdf/ PoliticaNacionaldeSaudedaPessoaIdosa.pdf

Received: June 27, 2017

Reviewed: September 09, 2017

Accepted: November 05, 2017 